\title{
MULTI-PRODUCT EXPORTERS AND THE MARGINS OF TRADE*
}

\author{
By ANDREW B. BERNARD†, ILKE VAN BEVEREN\$ and \\ HYLKE VANDENBUSSCHE
}

$\dagger$ Tuck School of Business at Dartmouth, Centre for Economic Policy Research and National Bureau of Economic Research \$Lessius Department of Business Studies, KULeuven CES and LICOS, and National Bank of Belgium §IRES-CORE, Université Catholique de Louvain, KULeuven-LICOS, National Bank of Belgium and Centre for Economic Policy Research

\begin{abstract}
The present paper examines multi-product exporters in Belgium, considering their importance and the relationship between the margins of trade and firm productivity. We use proxies for trade costs to quantify the extensive and intensive margin adjustments of trade. Relatively few exporting firms account for the majority of Belgian exports and these large firms have greater productivity and value-added, more employees and more exported products than smaller exporters. Across firms, productivity is positively associated with firm exports. More productive firms export more products to more countries and have higher average product-country export flows. The extensive and intensive margins are equally important in total firm exports.

JEL Classification Numbers: F12, F13, F14, L11.
\end{abstract}

\section{Introduction}

This paper contributes to the small but growing literature documenting the prevalence and importance of multi-product firms. The study of multi-product firms allows for a much more detailed decomposition of exports than was possible in earlier more aggregate research which examined variation in export levels across firms. The recent availability of transaction-based data sets, with exports at the firm-level broken down by product and by destination, allows researchers to consider both the intensive margin of trade (i.e. increases in exports by a firm of a product) as well as several extensive margins, including the number of export destinations and the number of products per destination.

Until recently, stylized facts about the role of multi-product firms and the empirical support for new theories of multi-product exporters have mainly been tested on countries such as the USA and France with relatively low export to GDP ratios (11 and 26\% from the USA and France, respectively). ${ }^{1}$ In this paper, we study multi-product firms in the small open economy of Belgium, a country where exports are over $86 \%$ of GDP.

* Special thanks goes to Jean-Marc Troch at the National Bank of Belgium for assistance and help with the data. We are also grateful to Christophe Piette and Kris de Spiegelaere for data clarification and Danny Delcambre for providing us with supplementary files and help with the Combined Nomenclature concordance. Vandenbussche thanks ARC, UCL and Excellence Centre LICOS for support. This paper was written while Van Beveren and Vandenbussche were visiting the National Bank of Belgium. The views expressed in this paper are those of the authors and do not necessarily reflect the views of the National Bank of Belgium, the National Bureau of Economics Research or the Centre for Economic Policy Research.

1 Multi-product exporters are analysed in the USA by Bernard et al. (2009a; 2011), in France by Mayer et al. (2013), in Brazil and Chile by Arkolakis and Muendler (2011), in Mexico by Iacovone and Javorcik (2010), and in India by Goldberg et al. (2010). The export to GDP ratios of these countries are 11, 26, 15, 41,27 and $20 \%$, respectively. 
We use the empirical predictions of a recent theory model by Bernard et al. (2010) to guide our research on the margins of trade. That model is a static general equilibrium framework and develops predictions on long-run relationships between the margins of trade, firm productivity and trade costs. ${ }^{2}$ We consider both steady-state and short-run outcomes using a comprehensive panel of Belgium exports and their products and destinations from 1998 to 2005, which combines data on firms' exporting activities from the National Bank of Belgium's Trade Database with firm-level characteristics obtained from the Belgian Business Registry of firms. The panel dimension of the data allows us to study the within-firm adjustment of intensive and extensive margins of trade over time in response to productivity shocks and changes in trade costs faced by exporting firms.

The data allow us to examine how changes in firm-level productivity over time are correlated with firms' extensive margins, the number of products exported and the number of destination markets served by each firm, as well as average firm-product-country exports. This within-firm adjustment can usefully be compared to existing studies where the relationship between productivity and changes in firms' extensive and intensive margins of trade are considered in cross-section (Bernard et al., 2011; Mayer et al., 2014).

We measure trade costs in two different ways: through distance and exchange rate movements. The measures of trade costs differ in their degree of variation and level of detail. Distance varies by country but not over time, while exchange rates vary by country and year.

Our empirical findings on the full set of multi-product firms confirm the cross-sectional findings of earlier studies. Multi-product firms appear both prevalent and important in exports. Similar to what has been found in other countries, a few large firms, exporting many products, account for the majority of Belgian exports. Firm characteristics such as productivity, employment and capital intensity correlate positively with the number of products a firm exports.

Following existing empirical work, we decompose export flows both at the country and firm level into extensive and intensive margins. For aggregate Belgian exports to a given country, the extensive margins correspond to the number of firms serving the destination market and the number of products exported to that market, while the intensive margin is associated with the average exports per firm-product. At the level of the firm, extensive margins are the number of destination countries for the firm's exports and the number of products exported, while the intensive margin is the average exports by the firm to a country in a product.

The cross-section results confirm that more productive firms have higher values of export shipments. These greater shipments come, in part, from the extensive margins of trade; more productive firms reach more countries with more products. The average exports per firm-product-country are also significantly positively related to firm productivity in the cross-section and the intensive and extensive margins contribute roughly equally to the overall increase in firm exports. The findings are robust to alternative measures of firmlevel productivity.

Using the panel aspect of the data, we confirm the equal contributions of the intensive and extensive margins in response to increased firm productivity. Annual within-firm productivity increases are positively associated with the number of products exported and the number of destination markets served by the firm. Unsurprisingly, the magnitudes of the correlations using annual productivity changes are smaller than those in the cross-

2 A dynamic version of the model is presented in the online technical appendix to that paper and is based on the closed-economy multi-product firm framework in Bernard et al. (2010). 
section results. Results on within-firm productivity over a longer interval confirm the results and have magnitudes roughly in between the annual and cross-section estimates. When firms become more productive over time, they serve more markets and ship more products per destination, while at the same time their average shipments become larger. Over a longer interval, firms adjust relatively more along the extensive margin as their productivity rises.

Cross-sectional gravity regressions using distance as a proxy for trade costs confirm prior work on US and French data. Total Belgian exports to a destination country decrease the further away is the destination market. The decomposition of country-level exports shows that distance strongly negatively affects the number of firms per destination and the number of products per destination while average firm exports per destination do not vary with distance. The invariance of average exports to falling distance is driven by greater exports in existing firm-products combined with the arrival of new marginal firms and products with lower values of exports. Within firm-product groups, export value falls with distance.

For short-run changes in trade costs, we use the admittedly imperfect proxy of annual real bilateral exchange rate changes, while controlling for destination market size differences through GDP. As expected, an appreciation of the destination market's currency boosts Belgian exports. Decomposing exports into the extensive and intensive margins, again, we find that a destination market's currency appreciation results in a higher number of Belgian firms exporting a larger set of products and an increase in the shipment value for already-exported products. The adjustment of multi-product firms along the extensive margins is again roughly equal to the intensive margin changes.

The rest of the paper is organized as follows. In the next section we document the prevalence and importance of multi-product exporters in Belgium. We also examine how firm-characteristics vary with the number of exported products. Section 3 looks at productivity changes across and within firms and their relationship to the margins of trade. Section 4 studies how trade costs affect the decomposition of exports, both at the firm and country level. The final section concludes.

\section{Prevalence and importance of multi-product exporters in Belgium}

\subsection{Multi-product exporters}

Before discussing the presence of multi-product firms, we point out some facts about the data and about Belgian exports in general. The Belgian export data are obtained from the National Bank of Belgium's trade database, which covers the entire population of recorded trade flows. Exactly which trade flows are recorded (i.e. whether firms are required to report their trade transactions) depends on their value and destination. For extra-European Union (EU) trade, all transactions with a minimum value of $€ 1,000$ or weight of more than $1,000 \mathrm{~kg}$ have to be reported. For intra-EU trade, firms are only required to report their export flows if their total annual intra-EU export value is higher than $€ 250,000$. $^{3}$ The export

The cut-off for reporting intra-EU trade has increased over time. However, during the period considered in this paper (1998-2005), it has remained constant. National Bank of Belgium estimations indicate that the share of exports accounted for by firms exporting less than €250,000 per year amounts to an average $1.5 \%$ of total exports in each of the years in our sample. Hence, the coverage of the trade database is estimated to amount to approximately $98 \%$ of total export flows. We are grateful to Jean-Marc Troch for providing us with this information. 
data are recorded at the year-firm-product-country level; i.e. they provide information on firm-level export flows by eight-digit Combined Nomenclature (CN8) product and by destination country. ${ }^{4}$

In the sample used in the empirical analysis below, we exclude transactions that do not involve a "transfer of ownership with compensation". This implies that we omit transaction flows such as the return, replacement and repair of goods, and transactions without compensation (e.g. government support, and processing or repair transactions). We further exclude two large firms for confidentiality reasons as they dominate exports in particular export product classes. The resulting sample covers $85 \%$ of total reported export value between 1998 and 2005.

Our data also allow us to study within-firm changes in the extensive and intensive margins of trade over time. For this purpose we use panel data from 1998-2005 during which cut-off values for recorded trade do not change, allowing for consistent data comparison. To construct this panel data we concord the annual changes in the CN8 product classification over time, similar to Pierce and Schott's (2009) concordance of the US 10-digit Harmonized System classification. This is necessary to correctly assess the dynamics in terms of the number of products that firms export, to avoid misinterpreting a product classification change as an adjustment of firms' extensive product margin. More details on the concordance of the CN8 classification over time are provided in the Data Appendix.

In Table 1 we report some summary statistics on the cross-section sample for $2005 .{ }^{5}$ The top panel refers to all exporting firms, while the middle and bottom panels refer to intra-EU and extra-EU exports, respectively. We categorize firms according to the number of products they export. In subsequent columns we include the number of firms, the value of exports, the average number of export destinations, the average export values of the firm-product-country, the firm-product and the firm-country for all firms exporting the reported number of products.

In 2005 we have a total of 25,248 exporting firms with a total value of exports of over $€ 215$ bn representing more than 900,000 firm-product-country transactions. ${ }^{6}$ This sample includes firms operating in all sectors, including both manufacturing and nonmanufacturing firms. Despite the fact that the inclusion cut-off is higher for intra-EU exports, the large majority of Belgian exports, $73 \%$, are intra-EU. This can be seen by relating the total export value for "internal" EU trade in the middle panel of $€ 157 \mathrm{bn}$ to overall exports of $€ 215 \mathrm{bn}$ of the top panel. ${ }^{7}$

Table 1 shows that multi-product exporters constitute the large majority of firms. Over $65 \%$ of all exporters are multi-product firms, they account for $98 \%$ of the total export value in 2005 . For the USA, the numbers are comparable, as $58 \%$ of US exporters are

4 The CN classification can be downloaded from the Eurostat Ramon server: http://ec.europa.eu/eurostat/ ramon/. Unless stated otherwise, our results use the full sample of destinations and are not sensitive to the exclusion of intra-EU destinations (to which the reporting cut-off applies). Results for the subsamples are available upon request from the authors.

5 More information on sample selection and the product classification is provided in the Data Appendix (available in the online version of this paper).

6 The number of exporters in 2005 is very close to the average number of exporters for the period 1998-2005.

7 The finding that there are more firms exporting extra-EU is most likely driven by the higher reporting cut-off for intra-EU trade. Although NBB estimations suggest that the value of omitted trade due to the reporting cut-off is only $1.5 \%$, the \%age of firms excluded is likely to be much higher. 
The Japanese Economic Review

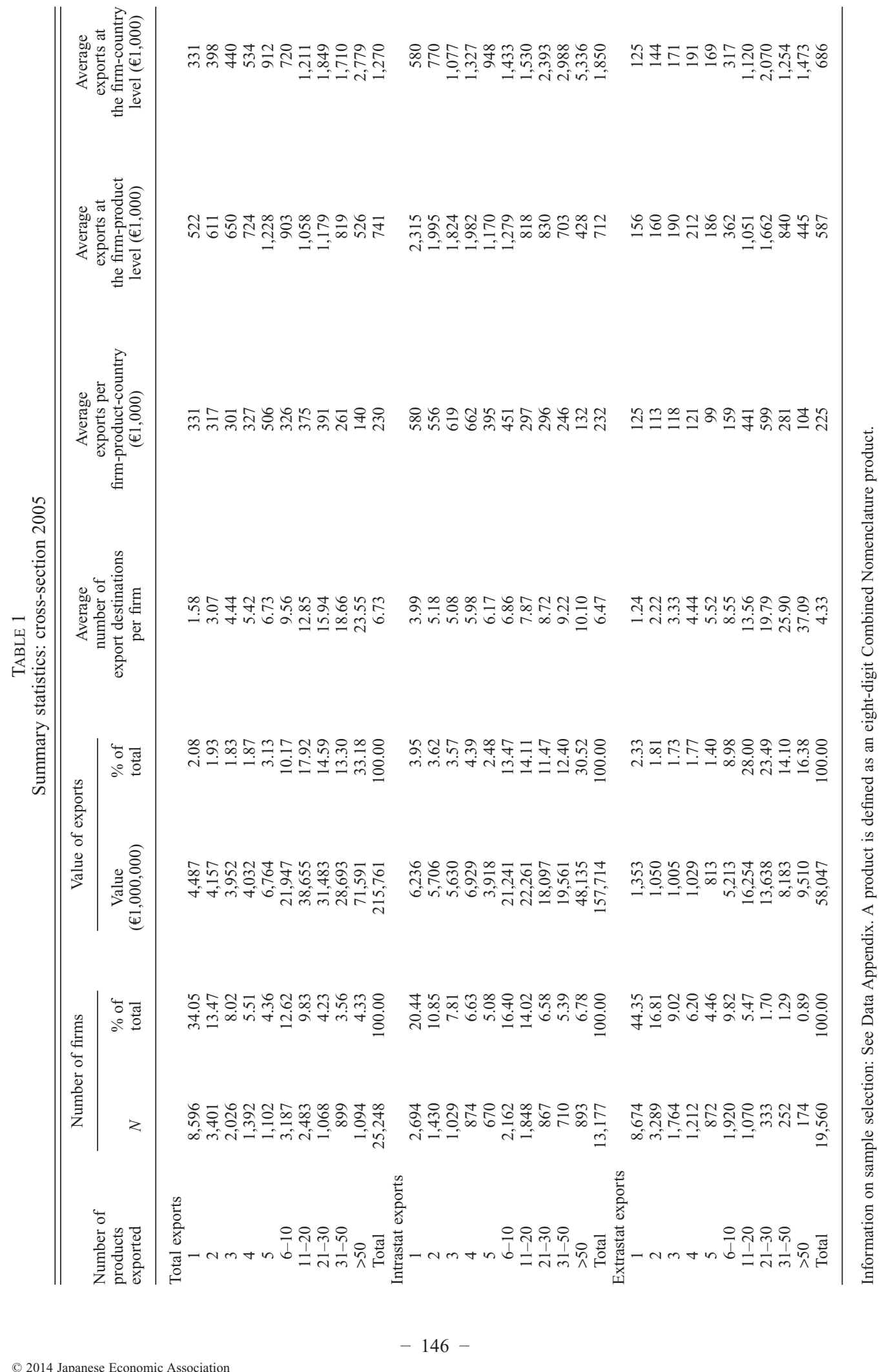


multi-product and account for more than $99 \%$ of exports (see Bernard et al., 2007). Single-product exporters account for $34 \%$ of firms but represent only $2 \%$ of exports. Relatively few firms export more than 20 products but these $12 \%$ of firms still account for $61 \%$ of exports. These results are very much in line with what is reported by Bernard et al. (2011) for the USA, Mayer and Ottaviano (2008) for France and Goldberg et al. (2010) for India and confirm the notion of "superstar" exporters where a small club of firms account for the large majority of exports. ${ }^{8}$

The average number of export destinations per firm is 6.73 , but this average hides substantial heterogeneity across firms. Firms that export just one product ship it to only 1.58 destination markets whereas firms exporting more than 50 products on average reach 23 different destinations, as shown in the top panel of Table 1. This finding is in line with recent theory papers on multi-product exporters where higher firm productivity leads the firm to serve more destinations and export more products per destination. ${ }^{9}$

The average exports per firm-product-country appears to vary non-monotonically as the number of export products increases. On average, single product exporters export $€ 331,000$ per destination while firms that export more than 50 products ship, on average, $€ 140,000$ per product to each market. The absence of a positive correlation between the number of exported products and average firm-product-country exports is in line with what has been reported for the USA by Bernard et al. (2007). Exports per firm-product also do not vary systematically with the number of products. In contrast, exports per country are increasing in the number of products exported; the rise in products per country offsets the lower shipments per product.

Despite the fact that the average firm-product-country export flow is not increasing with the number of exported products, multi-product exporters, on average, sell more than the average single product firm. Average firm-level exports (column 3 divided by column 1) are increasing in the number of products exported. The increased number of products and destinations more than offset the fall in average shipments.

\subsection{Multi-product exporters and firm characteristics}

In this subsection we bring together firm-level export data with firm-level balance sheet data to study the link between the number of exported products and indicators of firm-level productivity and size. ${ }^{10}$ In Table 2 we report the mean value of a set of firm characteristics (in logs) for total exporters. Firm characteristics include total factor productivity (TFP), ${ }^{11}$ value-added, number of employees (full-time equivalent units) and capital intensity (defined as tangible fixed assets per employee).

8 Results are different for Mexico where most exports come from single product exporters (Iacovone and Javorcik, 2010),

9 Models of multi-product exporters include Eckel and Neary (2010), Bernard et al. (2011), Arkolakis and Muendler (2011), Mayer et al. (2014) and Feenstra and Ma (2009). A common feature of these models is that higher firm productivity increases total firm exports and the number of products exported.

10 Selection on availability of firm-level characteristics such as employment, value-added and tangible fixed assets imposes another restriction on the sample selection; i.e. only those firms with positive values for all firm characteristics can be included in the analysis. Compared to total reported exports, the sample of firms with available data on firm characteristics (positive value added and employment) accounts for $54 \%$ of total export value between 1998 and 2005.

11 To obtain comparable levels of TFP across firms, we apply the Caves et al. (1982) methodology. Hence, TFP is calculated as an index, calculated by comparing each firm to a hypothetical firm, where the hypothetical firm is defined as the average over all firms in a two-digit NACE sector and year. 
TABLE 2

Firm characteristics: Cross-section 2005

\begin{tabular}{lcccc}
\hline \hline $\begin{array}{l}\text { Number of products } \\
\text { exported }\end{array}$ & $\begin{array}{c}\ln \text { (Total factor } \\
\text { productivity) }\end{array}$ & $\begin{array}{c}\ln (\text { Value } \\
\text { added })\end{array}$ & $\begin{array}{c}\ln \text { (Employment) } \\
\text { ln(Capital } \\
\text { intensity) }\end{array}$ \\
\hline $\begin{array}{l}\text { Total exports: All firms } \\
1\end{array}$ & -0.35 & 12.74 & & 10.20 \\
2 & -0.12 & 13.05 & 1.69 & 10.15 \\
3 & -0.21 & 13.27 & 2.11 & 10.28 \\
4 & -0.15 & 13.39 & 2.24 & 10.27 \\
5 & -0.14 & 13.48 & 2.28 & 10.24 \\
$6-10$ & -0.14 & 13.72 & 2.50 & 10.23 \\
$11-20$ & -0.07 & 14.02 & 2.76 & 10.17 \\
$21-30$ & -0.08 & 14.26 & 2.96 & 10.21 \\
$31-50$ & -0.03 & 14.64 & 3.33 & 10.10 \\
$>50$ & 0.00 & 15.06 & 3.78 & 10.07 \\
\hline
\end{tabular}

Information on sample selection: See Data Appendix. A product is defined as an eight-digit Combined Nomenclature product. All values are expressed in euros. Total factor productivity is calculated using the index number methodology (Caves et al., 1982). Employment is expressed in full-time equivalent units. Capital intensity is defined as tangible fixed assets per employee. Values reported are firm-level sample means, taken over all firms exporting the listed number of products.

The data confirm that firm productivity, value-added and employment are all higher for firms that export more products, while average capital intensity declines slightly as firms export more products. Firm-level employment, which is generally regarded as an indicator of firm size, reveals that firms exporting over 50 products are approximately eight times as large as firms exporting a single product. Value-added also rises as firms export more products. The mean value-added for firms exporting $50+$ products is approximately ten times as large as that of single product firms.

\subsection{Modelling multi-product firms}

The empirical analysis in this paper closely follows the theoretical and empirical work in Bernard et al. (2007). Their approach generalizes the standard single-product heterogeneous-firm model of trade to allow firms to produce a set of horizontally differentiated products that are potentially exported to many countries. ${ }^{12}$ Firms differ according to their underlying ability and products vary in their profitability across both firms and markets. Firms must pay a country-specific fixed cost to export regardless of the number of products sent to the country as well as a product-country fixed cost for each product in each market.

Increases in firm ability are associated with increased exports of existing products in existing markets, new products exported to existing markets and new markets for the most profitable products. A reduction in variable trade costs is associated with increased exports of existing products in the market, new products from current exporters and new firms exporting to the market. Bernard et al. (2011) examine the empirical implications of the model using cross-section US data and confirm of the major predictions of the model. We consider the model's predictions in the Belgian data in the cross-section and over time.

12 The model allows for products to be produced and exported but not sold in the domestic market. It does not envision exports of goods that the firm does not produce. 


\section{Firm productivity and exports}

A common component to many models of multi-product firms and exporting is the relationship between underlying firm productivity and the margins of trade. Increases in actual firm productivity, as opposed to measured productivity, raise exports of existing products to existing markets, allow firms to enter new markets with existing products and make profitable the export of new previously marginal products. Aggregate firm exports are expected to go up in response to higher firm productivity while the number of markets served and products exported also increase. Measures of average firm exports to a particular destination or average exports per product-destination may or may not rise due to the confounding effects of increasing exports within product-country and the arrival of new marginal products and countries.

In this section we examine the role of firm productivity in aggregate firm exports and consider the role of both country and product extensive margins as well as the intensive margin of average shipments per product-country. While previous empirical research examined the role of variation in productivity across firms (Bernard et al., 2011), we are able to consider both the cross-sectional variation in firm productivity as well as withinfirm changes over time.

Measurement of "true" firm productivity is problematic both for single-product firms that can choose between products with different production technologies or demand characteristics (Bernard et al., 2009b) and for multi-product firms where inputs are measured at the firm level or plant level rather than per product (De Loecker, 2011). Several measures can be used to proxy underlying firm productivity. Our preferred measures are valueadded-based TFP and value-added per worker (labour productivity). ${ }^{13}$

\subsection{Cross-sectional evidence}

We follow the empirical strategy of Bernard et al. (2011) and relate the margins of firm trade to proxies for firm productivity. Total firm exports can be decomposed into the number of destination countries served by the firm, $C_{f}$, the number of distinct products exported, $P_{f}$, a measure of coverage or density that corresponds to the share of the firms exported products sent to the average destination, $D_{f}$, and the average exports per productcountry served, $\bar{X}_{f}$,

$$
\begin{aligned}
X_{f} & =C_{f} P_{f} D_{f} \bar{X}_{f} \\
\text { where } D_{f} & =\frac{o_{c p f}}{C_{f} P_{f}} \text { and } \bar{X}_{f}=\frac{1}{o_{c p f}} \sum_{c} \sum_{p} X_{c p f}
\end{aligned}
$$

and $o_{c p f}$ refers to the number of positive firm-level export transactions at the productcountry level. The measure of density considers how many country-product combinations are being actively served by the exporter. If the firm exports 10 unique products and exports to 10 destination markets then the total possible number of country-product combinations

13 Bernard et al. (2011) additionally consider the responses of the extensive and intensive margins of trade to other proxies, including the number of products exported, exports of the largest product and (for a subset of firms) exports of the fifth largest product. The authors show that these measures are positively correlated with underlying firm productivity in their multi-product firm model where an increase in firm productivity lowers the (constant) marginal cost of production of all products. 
TABLE 3

Firm productivity and the margins of trade: 2005

\begin{tabular}{|c|c|c|c|c|c|c|}
\hline & $\ln \left(\right.$ Value $\left._{f}\right)$ & $\ln \left(\#\right.$ Countries $\left._{f}\right)$ & $\ln (\#$ Products $)$ & $\ln \left(\right.$ Density $\left._{f}\right)$ & $\begin{array}{c}\ln \left(\text { Average }^{\text {Aalue }}\right) \\
\text { (a) }\end{array}$ & $\ln \left(\right.$ Value $\left._{f p c}\right)$ \\
\hline \multicolumn{7}{|c|}{ Using TFP to proxy for firm productivity } \\
\hline $\operatorname{Ln}(T F P)$ & $\begin{array}{l}0.076^{* *} \\
{[0.035]}\end{array}$ & $\begin{array}{c}0.022 * * \\
{[0.011]}\end{array}$ & $\begin{array}{l}0.027 * * \\
{[0.012]}\end{array}$ & $\begin{array}{c}-0.013^{* *} \\
{[0.007]}\end{array}$ & $\begin{array}{l}0.040 * * \\
{[0.020]}\end{array}$ & $\begin{array}{l}0.094 * * * \\
{[0.035]}\end{array}$ \\
\hline Fixed effects & Industry & Industry & Industry & Industry & Industry & Product-country \\
\hline Clustering & No & No & No & No & No & Firm \\
\hline Observations & 16,278 & 16,278 & 16,278 & 16,278 & 16,278 & 684,860 \\
\hline$R^{2}$ & 0.241 & 0.194 & 0.143 & 0.139 & 0.221 & 0.405 \\
\hline \multicolumn{7}{|c|}{ Using labour productivity (value added per worker) to proxy for firm productivity } \\
\hline $\ln (V A /$ worker $)$ & $\begin{array}{l}0.762 * * * \\
0.032]\end{array}$ & $\begin{array}{c}0.199 * * * \\
{[0.012]}\end{array}$ & $\begin{array}{l}0.173 * * * \\
{[0.015]}\end{array}$ & $\begin{array}{l}-0.101 * * * \\
{[0.008]}\end{array}$ & $\begin{array}{l}0.491 * * * \\
0.022]\end{array}$ & $\begin{array}{l}0.309 * * * \\
{[0.076]}\end{array}$ \\
\hline Fixed effects & Industry & Industry & Industry & Industry & Industry & Product-country \\
\hline Clustering & No & No & No & No & No & Firm \\
\hline Observations & 16,499 & 16,499 & 16,499 & 16,499 & 16,499 & 689,269 \\
\hline$R^{2}$ & 0.267 & 0.204 & 0.147 & 0.146 & 0.246 & 0.408 \\
\hline
\end{tabular}

All results are obtained by running ordinary least squares regressions at the firm level, using data on total exports for 2005 (see Data Appendix for sample selection). The dependent variable used is reported at the top of each column. Reported values are coefficients [robust standard errors]. Significance levels: $* * *<0.01 ; * *<0.05$. TFP, total factor productivity; VA, value added.

is 100. If, on average, the firm exports two products to each market, the density of export activity for the firm is $0.2 .^{14}$

In Table 3 we report separate cross-section regressions for 2005 of $\log$ firm exports and its four constituent components on measures of log TFP (top panel) and log value-added per worker (bottom panel), including fixed effects for the major industry of the firm:

$$
\ln Y_{f}=c+\beta \ln \operatorname{Prod}_{f}+\delta_{i}+\varepsilon_{f},
$$

where $Y_{f}$ refers to the four components of the decomposition given by (1), i.e. $C_{f}, P_{f}, D_{f}$ and $\bar{X}_{f}$. By construction the specification only examines the relationship of productivity and exports for current exporters.

Column 1 of Table 3 considers the response of $\log$ total firm exports to differences in measured productivity across firms. As expected both TFP and value-added per worker are positive and significant; a $10 \%$ increase in TFP is associated with a $0.7 \%$ increase in firm exports while a comparable increase in value-added per worker is associated with a $7.6 \%$ increase in firm exports.

Looking at the extensive margins (columns 2-4), we find that the number of destinations and products are increasing in firm productivity. The density measure falls with productivity as more productive firms export more products and reach more destinations but do not ship every product to every country. The number of products per country, $P_{f} D_{f}$, is higher for firms with higher measured productivity. Column 5 of Table 3 reports results where the dependent variable is the average value of firm-level shipments per product-country (in logs). Interestingly, this value is also strongly rising in productivity. Theoretical predictions

14 Bernard et al. (2007) introduce the idea of density in the context of bilateral US exports across countries. 
A. B. Bernard, I. Van Beveren, H. Vandenbussche: Exporters and the Margins of Trade

TABLE 4

Within-firm productivity changes and the margins of trade

\begin{tabular}{|c|c|c|c|c|c|}
\hline & $\ln \left(\right.$ Value $\left._{f}\right)$ & $\ln \left(\#\right.$ Countries $\left._{f}\right)$ & $\ln (\#$ Products $)$ & $\ln \left({\left.\text { Average } \text { value }_{f}\right)}\right.$ & $\ln \left(\right.$ Value $\left._{f p c}\right)$ \\
\hline \multicolumn{6}{|c|}{ Annual differences } \\
\hline \multirow[t]{2}{*}{$\operatorname{Ln}(T F P)$} & $0.005^{* *}$ & $0.002 * * *$ & $0.001 *$ & $0.002 *$ & 0.002 \\
\hline & {$[0.002]$} & {$[0.001]$} & {$[0.001]$} & {$[0.001]$} & {$[0.002]$} \\
\hline Fixed effects & Firm, year & Firm, year & Firm, year & Firm, year & Firm-product-country + \\
\hline Clustering & No & No & No & No & Year firm \\
\hline Observations & 135,077 & 135,077 & 135,077 & 135,077 & $4,686,642$ \\
\hline$R^{2}$ & 0.890 & 0.890 & 0.880 & 0.870 & 0.890 \\
\hline \multicolumn{6}{|c|}{ Long differences (1998-2005) } \\
\hline \multirow[t]{2}{*}{$\operatorname{Ln}(T F P)$} & $0.032 * *$ & $0.012 * *$ & $0.018 * *$ & $0.016^{* *}$ & $0.073 * * *$ \\
\hline & {$[0.014]$} & {$[0.005]$} & {$[0.008]$} & {$[0.008]$} & {$[0.018]$} \\
\hline Fixed effects & None & None & None & None & None \\
\hline Clustering & No & No & No & No & Firm \\
\hline Observations & 8,648 & 8,648 & 8,648 & 8,648 & 165,594 \\
\hline$R^{2}$ & 0.002 & 0.002 & 0.002 & 0.001 & 0.002 \\
\hline
\end{tabular}

All results are obtained by running regressions at the firm level or at the firm-product-country level (final column), using data on total exports between 1998 and 2005 (see Data Appendix for sample selection). The dependent variable used is reported at the top of each column. Reported values are coefficients [robust standard errors]. The top panel reports the results of a fixed effects regression (within-firm results). In the bottom panel both the dependent and independent variables are defined as long differences (i.e. the difference between 2005 and 1998). Significance levels: $* * *<0.01 ; * *<0.05 ; *<0.1$.

for average shipments are ambiguous due to the positive effect of increasing shipments for a given product to a given country combined with the negative effect of marginal countries and marginal products entering the export mix. In the final column we report the within country-product response to differences in firm productivity. The coefficients for both log TFP and log value-added per worker are positive as expected; higher productivity at the firm is associated with greater shipments of a given product to a given country. The coefficient in the value-added regression is less than the corresponding coefficient on average shipments per product-country, which is somewhat surprising as the expectation is that added product-country combinations should have lower sales than existing exported pairs.

If we interpret the cross-firm regressions as a proxy for the steady-state, or long-run, distribution, we find that more than half the aggregate increase in firm exports associated with higher firm productivity comes from the intensive margin.

\subsection{Changes in productivity over time}

The results of the previous subsection provide strong evidence that in the cross-section higher firm productivity is associated with increased exports both because of the extensive margins of more destinations and more products per destination and because average shipments per product-destination are higher for more productive firms.

The panel nature of our data allows us to examine a more precise prediction of the multi-product models that within-firm increases in productivity should be associated with increases in total exports and with increases in both the number of destination markets served and the number of products exported. In the top panel of Table 4, we report estimates from a panel regression of the form 


$$
\Delta \ln Y_{f t}=\alpha+\beta \Delta \ln \operatorname{Prod}_{f t}+\delta_{f}+\delta_{t}+\varepsilon_{f t}
$$

where $Y_{f t}$ is a component of the decomposition of firm exports given by Equation (1) and $\delta_{f}$ and $\delta_{t}$ are firm and year fixed effects, respectively. This specification is run on firms that export in consecutive years, ignoring potential problems related to selection into exporting and firm productivity.

The results confirm the expected positive and significant correlation of measured firm TFP with total firm exports; however, the magnitude of the relationship in these annual changes is much smaller than that found in the cross-section regression reported above. Both the product and country extensive margins increase with firm productivity and contribute to the overall increases in exports. Within-firm increases in TFP are correlated with increases in the average value of exports at the firm level and the role of the intensive margin is comparable in magnitude to that of the extensive margin. Again, in the final column, within country-product pairs we find the expected positive and significant coefficient.

The second panel of Table 4 reports results of a specification in long differences, 1998-2005 for the same set of dependent variables. This regression is limited to firms that exported in both 1998 and 2005. Here, we find a stronger relationship between productivity growth and increases in export value. Again, both the extensive and intensive margins contribute equally, although unlike the annual changes, stronger effects on both the number of countries and the number of products are offset by a decline in the density of productcountry coverage by the firm. The within country-product export growth is strongly positively correlated to changes in productivity.

\section{Trade costs and exports}

The basic theoretical frameworks for multi-product exporters consider the effects of symmetric reductions in ad valorem trade costs across countries and products. ${ }^{15}$ Unfortunately, during the period of availability for detailed trade transaction data, there are relatively few episodes of liberalization. Bernard et al. (2011) and Baldwin and Gu (2009) consider the effects of the 1987 Canada-US Free Trade Agreement. They examine domestic production data for multi-product firms and find confirmation of the major prediction of the multi-product models that firms facing larger tariff reductions implement larger cuts in the range of total products and increase the skewness of their output mix.

We approach the question of how firms respond to reductions in trade costs in two ways. First, following Bernard et al. (2011), we look at the response of total exports and the margins of trade to distance in a simple cross-country gravity regression. Next we consider annual changes in the real bilateral exchange rate as a proxy for trade cost changes for Belgian exporters over shorter time horizons.

\subsection{Distance and the margins of trade}

We start with a simple gravity equation specification to examine the relationship between distance to Belgium and the variation of the extensive and intensive margins of trade. The gravity equation approximates the long-run equilibrium relationship of exports to distance

15 Eckel and Neary (2010) consider globalization through the addition of new countries increasing potential markets for oligopolistic multi-product exporting firms. 
A. B. Bernard, I. Van Beveren, H. Vandenbussche: Exporters and the Margins of Trade

TABLE 5

Gravity and the margins of Belgian bilateral exports

\begin{tabular}{|c|c|c|c|c|c|}
\hline & $\ln \left(\right.$ Value $\left._{c}\right)$ & $\ln \left(\#\right.$ Firms $\left._{c}\right)$ & $\ln \left(\#\right.$ Products $\left._{c}\right)$ & $\ln \left(\right.$ Density $\left._{c}\right)$ & $\ln \left(\right.$ Average value $\left._{c}\right)$ \\
\hline \multirow{2}{*}{$\operatorname{Ln}\left(\right.$ Distance $\left._{c}\right)$} & $-0.966 * * *$ & $-0.777 * * *$ & $-0.679 * * *$ & $0.438 * * *$ & 0.051 \\
\hline & {$[0.077]$} & {$[0.063]$} & {$[0.074]$} & {$[0.067]$} & {$[0.044]$} \\
\hline \multirow[t]{2}{*}{$\operatorname{Ln}\left(G D P_{c}\right)$} & $0.954 * * *$ & $0.516^{* * *}$ & $0.528^{* * *}$ & $-0.429^{* * *}$ & $0.340^{* * *}$ \\
\hline & {$[0.038]$} & {$[0.028]$} & {$[0.030]$} & {$[0.026]$} & {$[0.022]$} \\
\hline Fixed effects & None & none & None & none & None \\
\hline Observations & 178 & 178 & 178 & 178 & 178 \\
\hline$R^{2}$ & 0.872 & 0.790 & 0.783 & 0.745 & 0.634 \\
\hline
\end{tabular}

All results are obtained by running regressions at the country level or at the firm-product-country level (final data on total exports in 2005 (see Data Appendix for sample selection). The dependent variable used is repo each column. Reported values are coefficients [robust standard errors]. Distance refers to the great-circle distance between Brussels and the capital of country $c$. GDP is defined as nominal GDP, expressed in euros. Significance level $* * *<0.01$

and GDP. The coefficient on distance in the gravity equation gives us a proxy for the responses of the margins of trade to trade cost changes. Following Bernard et al. (2011), we decompose total bilateral exports to country $c\left(X_{c}\right)$ into components including the number of Belgium firms exporting to country $F_{c}$, the number of distinct $\mathrm{CN} 8$ products exported to the country, $P_{c}$, the density of trade defined as the fraction of firm-product combinations with positive exports, $D_{c}$, and the average value of exports per firm-product going to the country conditional on positive exports, $\bar{X}_{c}$,

$$
\begin{aligned}
X_{c} & =F_{c} P_{c} D_{c} \bar{X}_{c} \\
\text { where } D_{c} & =\frac{o_{p f c}}{C_{c} P_{c}} \text { and } \bar{X}_{c}=\frac{1}{o_{p f c}} \sum_{f} \sum_{p} X_{c p f}
\end{aligned}
$$

and $o_{p f c}$ is the number of active firm-products in country $c$. We regress total exports to trade partners, as well as each component of total exports, on the great-circle distance of trade partners from Belgium, obtained from the CEPII database Mayer and Zignago (2011). To control for market size, we also include the log of nominal GDP of the destination market, obtained from the World Development Indicators database of the World Bank (2010),

$$
\ln Y_{c}=\alpha+\beta \ln \text { Distance }_{c}+\gamma \ln \mathrm{GDP}_{c}+\varepsilon_{c},
$$

where $Y_{c}$ is a component of Belgian exports given in Equation (4).

Table 5 reports the regression results using 2005 data: results for other years are similar. The first column of Table 5 confirms the long-established result that aggregate bilateral exports are strongly decreasing in distance and increasing in destination market GDP; coefficients on both distance and destination GDP are near one in absolute value.

The next three columns of the table report the effects of distance and GDP on the extensive margins of trade. As found by Bernard et al. (2011), both the number of firms and the number of products increase as trade costs fall across countries, while the density of trade is increasing with distance. ${ }^{16}$ The combined effect of the extensive margins, seen by

16 Density is expected to be lower for markets that are served by more firms and that receive more products. As the number of products exported rises, each firm will be exporting a smaller share of the range of the products because firms are active in a limited subset of products and industries. 
adding the coefficients on distance across columns 2-4, almost completely explains the cross-country variation in export value. In the long run, lower trade costs translate into higher exports through an increase in the number of firms serving the destination and an increase in products per firm.

Column 5 reports the effect of distance on the average value of exports per firm-product to the country. In a world where firms export a single product to multiple countries, this coefficient would be expected to be negative and significant; i.e. exports of any given product should increase if trade costs are lower. In a world with multi-product exporters, however, the relationship between distance and average shipments per firm-product is ambiguous both because new marginal exporters are able to enter less costly markets and because existing exporters are able to ship lower profit products to closer markets. Our results confirm those of Bernard et al. (2011) in that we find a small, insignificant positive coefficient for distance on average exports.

However, in column 6 we report the results of a gravity-style regression where the dependent variable is the log of firm-product-country exports and we control for firmproduct fixed effects. Now distance again plays the expected role; for any given product exported by a firm, the value of exports is decreasing in trade costs as measured by distance to the destination country.

\subsection{Exchange rates and the margins of trade}

Exchange rates play a complicated role in firm decision-making that links market structure, firm market power and other issues. An extensive literature considers pricing-to-market by firms as well as aggregate implications for the price level and the role of sunk costs in mitigating short-run responses to exchange rate movements (see Goldberg and Knetter, 1997; Gopinath and Itskhoki, 2010). Here, we abstract from these issues and consider a simple specification relating bilateral exchange rate changes with firm-level responses of Belgian exporters, including both extensive and intensive margin adjustments. The base specification is

$$
\Delta \ln Y_{c t}=\alpha+\beta \Delta \ln R E R_{c t}+\gamma \Delta \ln G D P_{c t}+\delta_{c}+\varepsilon_{c t}
$$

where $\Delta \ln Y_{c t}$ represents the annual log change in the components of the decomposition of total exports to country $c$ in year $t ; \Delta \ln R E R_{c t}$ is the change in the log of the real bilateral exchange rate of the Belgian currency (franc, then euro) expressed in units of foreign currency per unit of Belgian currency; $\Delta \ln G D P_{c t}$ is the change in the log of the real GDP of the foreign country expressed in constant local currency units. The real exchange rate $\left(R E R_{c t}\right)$ is constructed using data on exchange rates and domestic and foreign price evolutions from the International Financial Statistics database (IMF, 2010). Specifically, the real exchange rate is defined as:

$$
R E R_{c t}=E R_{c t}\left(\frac{C P I_{b e, t}}{C P I_{c, t}}\right)
$$

where $E R_{c t}$ is the nominal Belgian exchange rate expressed in units of foreign currency per unit of Belgian currency and $C P I_{b e, t}\left(C P I_{c t}\right)$ refers to the domestic (foreign) consumer price index. GDP data are taken from the World Development Indicators database (World Bank, 2010). 
A. B. Bernard, I. Van Beveren, H. Vandenbussche: Exporters and the Margins of Trade

TABLE 6

Exchange rates and the margins of trade over time

\begin{tabular}{|c|c|c|c|c|c|c|}
\hline & $\Delta \ln \left(\right.$ Value $\left._{c}\right)$ & $\begin{array}{c}\Delta \ln (\# \\
\left.\text { Firms }_{c}\right)\end{array}$ & $\begin{array}{c}\Delta \ln (\# \\
\left.\text { Products }_{c}\right)\end{array}$ & $\Delta \ln \left(\right.$ Densityc $\left._{c}\right)$ & $\begin{array}{c}\Delta \ln (\text { Average } \\
\left.\text { value }_{c}\right)\end{array}$ & $\Delta \ln \left(\right.$ Value $\left._{f p c}\right)$ \\
\hline \multirow[t]{2}{*}{$\Delta \ln ($ Real exchange rate $)$} & $-0.512 * * *$ & $-0.167 * *$ & $-0.227 * * *$ & $0.153 * * *$ & $-0.270 * * *$ & $-0.546^{* * *}$ \\
\hline & {$[0.145]$} & {$[0.072]$} & {$[0.068]$} & {$[0.055]$} & {$[0.100]$} & {$[0.139]$} \\
\hline \multirow[t]{2}{*}{$\Delta \ln ($ realGDP $)$} & $2.351 * * *$ & $0.810 * *$ & $1.229 * * *$ & $-0.680^{*}$ & $0.991 * *$ & $0.742 * * *$ \\
\hline & {$[0.559]$} & {$[0.331]$} & {$[0.388]$} & {$[0.348]$} & {$[0.414]$} & {$[0.254]$} \\
\hline Country dummies & Yes & Yes & Yes & Yes & Yes & Yes \\
\hline Firm-product fixed effects & No & No & No & No & No & Yes \\
\hline Observations & 899 & 899 & 899 & 899 & 899 & 558,428 \\
\hline$R^{2}$ & 0.093 & 0.092 & 0.159 & 0.096 & 0.083 & 0.160 \\
\hline Clustering & No & No & No & No & No & Country-year \\
\hline
\end{tabular}

All results are obtained by running regressions at the country level or at the firm-product-country level (final column), using data on total exports between 1998 and 2005 (see Data Appendix for sample selection). The dependent variable used is reported at the top of each column. Reported values are coefficients [robust standard errors]. The dependent and independent variables are defined as annual differences. Significance levels: $* * *<0.01 ; * *<0.05 ; *<0.1$.

For this specification we only include countries outside the EU for several reasons: the adoption of the euro by many EU countries complicates exchange rate analysis during the sample period; the extent of real exchange rate variation inside the Eurozone is limited to variations in the price levels; and the cut-off for reported exports to EU countries is different than that for exports to extra-EU destinations. ${ }^{17}$

Table 6 reports results from estimating Equation (6) for the different components of the decomposition shown in Equation (4). ${ }^{18}$ The results reported in Table 6 suggest that a 1\% depreciation of the euro is associated with a $0.35 \%$ increase in Belgian exports. Summarizing the results, the increase in exports is driven both by changes along the extensive margins in response to depreciation (i.e. increases in the number of firms and the number of products), as well as by an increase in the average exports per firm-product. As with changes in firm productivity, the responses are roughly evenly split in magnitude between the intensive and extensive margins. As expected, the within firm-product response is strongly increasing as the Belgian currency depreciates. The lower magnitude of the average response across products and countries is driven by the entry of the firm into new marginally profitable country-product markets

\section{Conclusion}

This paper documents the importance of multi-product firms for a small open economy using the universe of Belgian firm-level data with information on products and destination markets. We examine the role of multi-product firms in light of recent theoretical models.

17 The 10 accession countries in 2004 are also excluded from the analysis.

18 The addition of year fixed effects removes responses associated with overall annual fluctuations in the Belgian currency and, therefore, reduces the response of each of the components. 
In addition, we use the unique panel features of the Belgian data to examine the adjustments of the margins of trade in both the short run and long run both for aggregate Belgian exports and firm-level exports.

Multi-product firms in Belgium constitute $65 \%$ of all exporting firms and account for $98 \%$ of exports. Relatively few exporting firms account for the majority of Belgian exports and these large exporting firms have greater productivity, number of employees, valueadded and numbers of exported products.

Across firms, productivity is positively and significantly associated with the value of firm exports. More productive firms export more products to more countries and also have higher average product-country export flows. The extensive and intensive margins each account for approximately half of the variation in total firm exports. Country-level Belgian exports decrease as trade costs rise. A decomposition of country-level exports shows that trade costs are negatively correlated with the number of firms exporting to the country as well as the number of products per destination.

This paper both confirms recent findings about the importance of multi-product exporters and their ability to export many products to many destinations.

Final version accepted 22 October 2013.

\section{REFERENCES}

Arkolakis, C. and M.-A. Muendler (2011) “The Extensive Margin of Exporting Goods: A Firm-Level Analysis”, Yale University, mimeograph.

Baldwin, J. and W. Gu (2009) "The Impact of Trade on Plant Scale, Production-Run Length and Diversification", in T. Dunne, J. B. Jensen and M. J. Roberts, eds, Producer Dynamics: New Evidence from Micro Data, Chicago: University of Chicago Press, pp. 557-595.

Bernard, A. B., J. B. Jensen, S. J. Redding and P. K. Schott (2007) "Firms in International Trade", Journal of Economic Perspectives, Vol. 21, No. 3, pp. 105-130.

,-- and P. K. Schott (2009a) "Importers, Exporters, and Multinationals: A Portrait of Firms in the U.S. That Trade Goods", in T. Dunne, J. B. Jensen and M. J. Roberts, eds, Producer Dynamics: New Evidence from Micro Data, Chicago: University of Chicago Press, (with J. Bradford Jensen and Peter K. Schott), pp. 513-552.

- S. J. Redding and P. K. Schott (2009b) "Products and Productivity", Scandinavian Journal of Economics, Vol. 111, No. 4, pp. 681-709. , — and - (2010) "Multiple-Product Firms and Product Switching", American Economic Review, Vol. 100, pp. 70-97.

, - and - (2011) "Multi-Product Firms and Trade Liberalization", Quarterly Journal of Economics, Vol. 126, No. 3, pp. 1271-1318.

Caves, D. W., L. R. Christensen and W. E. Diewert (1982) "The Economic Theory of Index Numbers and the Measurement of Input, Output and Productivity", Econometrica, Vol. 50, No. 6, pp. 1393-1414.

De Loecker, J. (2011) "Product Differentiation, Multi-Product Firms and Estimating the Impact of Trade Liberalization on Productivity", Econometrica, Vol. 79, No. 5, pp. 1407-1451.

Eckel, C. and Neary, P. (2010) "Multi-Product Firms and Flexible Manufacturing in the Global Economy," Review of Economic Studies, Vol. 77, No. 1, pp. 188-217.

Feenstra, R. C. and H. Ma (2009) "Optimal Choice of Product Scope for Multiproduct Firms under Monopolistic Competition", in E. Helpman, D. Marin and T. Verdier, eds, The Organization of Firms in A Global Economy, Cambridge, MA: Harvard University Press, pp. 173-199.

Goldberg, P. K., A. Khandelwal, N. Pavcnik and P. Topalova (2010) "Multi-Product Firms and Product Turnover in the Developing World: Evidence from India", Review of Economics and Statistics, Vol. 92, No. 4, pp. 1042-1049.

and M. K. Knetter (1997) "Goods Prices and Exchange Rates: What Have We Learned? ", Journal of Economic Literature, Vol. 35, No. 3, pp. 1243-1272.

Gopinath, G., and O. Itskhoki. 2010. "Frequency of Price Adjustment and Pass-through", Quarterly Journal of Economics, Vol. 125, No. 2, pp. 675-727

Iacovone, L. and B. S. Javorcik (2010) "Multi-Product Exporters: Product Churning, Uncertainty and Export Discoveries", Economic Journal, Vol. 120, pp. 481-499. 
A. B. Bernard, I. Van Beveren, H. Vandenbussche: Exporters and the Margins of Trade

IMF (2010) International Financial Database, Washington DC: International Monetary Fund.

Mayer, T., M. Melitz and G. Ottaviano (2014) "Market Size, Competition, and the Product Mix of Exporters", American Economic Review (forthcoming).

— and G. I. P. Ottaviano (2008) "The Happy Few: The Internationalisation of European Firms", Intereconomics, May/June, 135-148.

Mayer, T. and S. Zignago (2011) Notes on CEPII's distances measures : the GeoDist Database CEPII Working Paper 2011-25.

Pierce, J. and P. Schott (2009) A concordance between ten-digit U.S. Harmonized System Codes and SIC/NAICS product classes and industries, NBER Working Paper 15548.

World Bank (2010) World Development Indicators, Washington DC: The World Bank.

\section{Supporting information}

Additional Supporting Information may be found in the online version of this article at the publisher's web-site:

Appendix S1 Data Appendix to Multi-Product Exporters and the Margins of Trade. 